\title{
臨床 急性腎不全を合併した微小変化型
}

\author{
ネフローゼ症候群の 3 症例 \\ 杏林大学医学部第一内科辻正人○本橋 茂 蓬田 茂 有村義宏 \\ 井上明夫 中林公正 北本 清 長沢俊彦
}

概要 腎生検にて微小変化型ネフローゼ症候群と診断し, 経過中に急性腎不全を合併した 3 例 について報告した．年令は23，54，72才ですへてて男性．急性腎不全発症に関連すると思われる 薬物の使用はなかった，3例とも高度の低蛋白血症を認めていた，2例は透析導入後，短期間 で透析を離脱できた，急性腎不全の発症機序は，微小变化型ネフローゼ症候群の突然発症的な 大量蛋白尿による急激な低蛋白血症のために，腎血流量の減少とともに尿細管腔蛋白円柱と腎 間質浮腫による尿細管閉塞を生じ、急性腎不全をきたしたと推察された。急性腎不全は微小变 化型ネフローゼ症候群の重大な合併症のUとつであり，本症候群の治療・管理には，充分に注 意が必要である。

[日内会誌 $77: 1031 \sim 1036,1988$ ]

\section{緒 言}

従来，微小変化型ネフローゼ症候群 (MCNS) そのbのが急性腎不全を呈することは殆どないと されている。しかし，急性謷不全発症の明らかな 原因がないのにMCNSに急性腎不全が合併する 報告が近年とくに増加している ${ }^{11215)}$ ，その発症機 序は今だ不明であるが，最近我々もMCNSに急性 腎不全を合併した 3 症例を経験し，MCNSにおけ る急性腎不全発生機序を考察する5光で示唆にと むと考点られたので，その詳細を報告する。

$$
\text { 症例 }
$$

\section{1. 経過の概略}

症例 1：23才，男性。一般事務職員.

家族歴・既往歴：特になし。

現病歴：昭和61年 5 月下旬より全身の浮腫が 出現したため近医を受診し，尿蛋白 $3400 \mathrm{mg} / \mathrm{dl}$, TP 3.4g/dl, Alb 1.7g/dlにてネフローゼ症候群 の診断で，昭和 61 年 6 月 6 日に当院入院した。入 院直後より之尿が出現し, BUN 67.3mg/dl, Cr $4.4 \mathrm{mg} / \mathrm{dl}$ と急性腎不全を合併し, 入院翌日より血 液透析老導入した。透析開始後約20日で1000ml/ 日以上の利库を認めるとともに浮腫は消失し, 約 1 カ月で透析を離脱した。7月2日に腎生強を施 行. MCNSの診断にてプレドニゾロン $60 \mathrm{mg} /$ 日よ り投与開始した後，杘蛋白の減少を認め，昭和61 年 9 月には不完全宽解 I 型となり, 腎機能もBUN $15 \mathrm{mg} / \mathrm{dl}, \mathrm{Cr} 1.0 \mathrm{mg} / \mathrm{dl}$ に回復している。本症例の 経過の概要は図 1aに示した。

症例 2：54才, 男性. 司法書士.

家族歴：特になし。

既往歴：51才時に高血王学指摘されている。

現病歴： 昭和61年 4 月, 顔面・両下肢に浮腫 が出現し，某病院に入院. 尿蛋田 $30 \mathrm{~g} /$ 日， TP 3.7 $\mathrm{g} / \mathrm{dl}, \mathrm{Alb} 1.6 \mathrm{~g} / \mathrm{dl}$ でネフローゼ症候群の診断にて 5 月15日に珡生検施行. MCNSの診断でプレドニ ゾロン $50 \mathrm{mg} /$ 日より投与開始され尿蛋白の減少を 認めたが，ステロイド减量中以再発を認め，昭和 61年 8 月にステロイドパルス療法施行するもネフ ローゼ状態は改善せず10月になり之尿が出現し， 昭和61年10月16日当院に転院した。転院時, BUN

[昭和62年 8 月 31 日受稿]

Three cases of acute renal failure associated with minimal change nephrotic syndrome

Masahito Tsuji, Shigeru Motohashi, Shigeru Yomogida, Yoshihiro Arimura, Akio Inove, Kimimasa Nakabayashi, Kiyoshi Kitamoto and Toshihiko Nagasawa, The First Department of Internal Medicine, Kyorin University School of Medicine, Tokyo 
a 症例 1 .

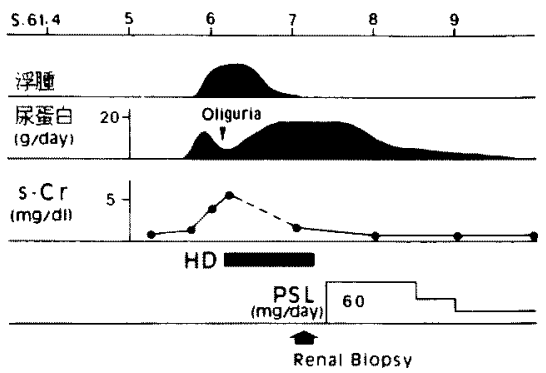

b 症例 2 .

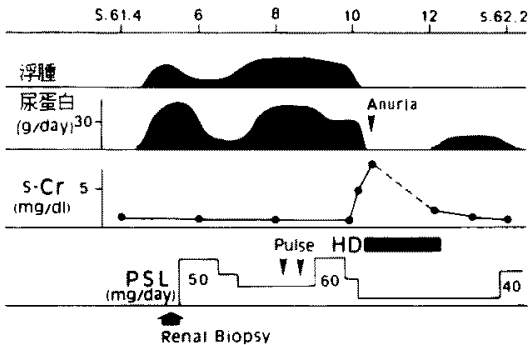

C 症例 3 .

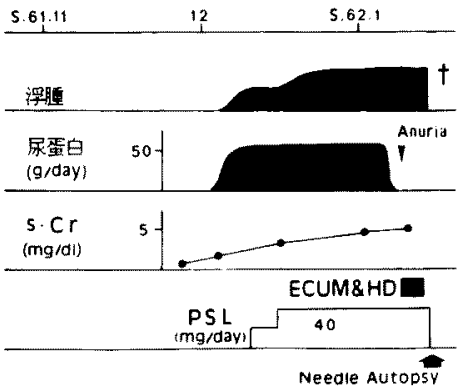

図 1.3 症例の臨床経過

$100 \mathrm{mg} / \mathrm{dl}, \mathrm{Cr} 7.6 \mathrm{mg} / \mathrm{dl}$ 認めたため，入院当日 から血液透析を導入した。透析開始後約 25 日より $1000 \mathrm{ml} /$ 日以上の利尿を認めるとともに浮腫は消 失し, 約 1 力月で透析を離脱した。昭和 62 年 2 月, プレドニゾロン $30 \mathrm{mg} /$ 日投与中で尿蛋白 $1 \mathrm{~g} /$ 日以 下, BUN 25mg/dl, Cr 2.3mg/dlk回復している. 本症例の経過の概要は図 $1 \mathrm{~b} に$ 示した。

症例 3：72才，男性。医師。

家族歴・既往歴：特になし。

現病歴： 昭和61年12月10日より全身浮腫が出 現し，尿蛋白 $1000 \mathrm{mg} /$ 日以上認められネフローゼ 症候群の診断でプレドニゾロン $30 \mathrm{mg} /$ 日を投与さ
表 1.入院時検查所見（急性腎不全合併時）

\begin{tabular}{|c|c|c|c|c|}
\hline & & 应例 1 & 症例 2 & 症例 3 \\
\hline \multicolumn{5}{|l|}{ 1. 末血 } \\
\hline $\mathrm{Hb}$ & $(\mathrm{g} / \mathrm{dl})$ & 15.6 & 10.2 & 9.3 \\
\hline $\mathrm{Ht}$ & $(\%)$ & 45.0 & 30.8 & 27.8 \\
\hline Plate. & $\left(\times 10^{4}\right)$ & 23.9 & 26.9 & 6.2 \\
\hline WBC & & 4300 & 9500 & 2600 \\
\hline \multicolumn{5}{|l|}{ 2. 生化学 } \\
\hline $\mathrm{Na}$ & $(\mathrm{mM})$ & 139 & 145 & 136 \\
\hline $\mathrm{K}$ & $(\mathrm{mM})$ & 4.9 & 3.8 & 4.7 \\
\hline $\mathrm{Cl}$ & $(\mathrm{mM})$ & 105 & 104 & 99 \\
\hline BUN & $(\mathrm{mg} / \mathrm{dl})$ & 67.3 & 102.3 & 154.0 \\
\hline $\mathrm{Cr}$ & $(\mathrm{mg} / \mathrm{dl})$ & 4.4 & 7.6 & 4.3 \\
\hline $\mathrm{TP}$ & $(\mathrm{g} / \mathrm{dl})$ & 3.6 & 4.4 & 3.5 \\
\hline Alb & $(\mathrm{g} / \mathrm{dl})$ & 1.7 & 1.7 & 1.8 \\
\hline GOT & $(\mathrm{U} / l)$ & 19 & 6 & 23 \\
\hline GPT & $(\mathrm{U} / l)$ & 37 & 16 & 21 \\
\hline $\mathrm{CPK}$ & $(\mathrm{mg} / \mathrm{dl})$ & 245 & 16 & 361 \\
\hline \multicolumn{5}{|c|}{ 3. 血请・免度 } \\
\hline $\operatorname{IgG}$ & $(\mathrm{mg} / \mathrm{dl})$ & 486 & 742 & 450 \\
\hline $\operatorname{Ig} A$ & $(\mathrm{mg} / \mathrm{dl})$ & 126 & 85 & 74 \\
\hline IgM & $(\mathrm{mg} / \mathrm{dl})$ & 146 & 147 & 35 \\
\hline $\operatorname{IgE}$ & $(\mathrm{IU} / \mathrm{ml})$ & 1942 & 50 & 351 \\
\hline $\mathrm{C}_{3}$ & $(\mathrm{mg} / \mathrm{dl})$ & 114 & 114 & 99 \\
\hline $\mathrm{C}_{4}$ & $(\mathrm{mg} / \mathrm{dl})$ & 69 & 67 & 50 \\
\hline $\mathrm{CH}_{50}$ & $(\mathrm{U} / \mathrm{ml})$ & 33 & 40 & ND \\
\hline ASO & & 80 & 40 & ND \\
\hline $\mathrm{HBAg}$ & & $(-)$ & $(-)$ & $(-)$ \\
\hline OKT4 & OKT8 & $45.8 / 28.6$ & $35.4 / 27.5$ & ND \\
\hline \multicolumn{5}{|c|}{ 4. 尿 } \\
\hline 蛋白 & $(\mathrm{mg} / \mathrm{dl})$ & 4210 & 5000 & $1000<$ \\
\hline 糖 & & $(-)$ & $(-)$ & $(-)$ \\
\hline 沈渣 & & & & \\
\hline $\mathrm{RBC}$ & $(F)$ & $0-1$ & $0 \sim 1$ & $0-1$ \\
\hline BMG & $(\mu \mathrm{g} / l)$ & 10754 & 5746 & ND \\
\hline NAG & $(\mathrm{U} / \mathrm{d})$ & 9.0 & 29.4 & ND \\
\hline
\end{tabular}

れるも全身浮腫は増悪傾向を呈した。昭和62年 1 月10日には無尿となり, 当院に緊急入院した。 TP $3.6 \mathrm{~g} / \mathrm{dl}$, Alb $1.8 \mathrm{~g} / \mathrm{dl}, \quad B U N 154 \mathrm{mg} / \mathrm{dl}$, Cr 4.3 $\mathrm{mg} / \mathrm{dl}$ を認め, 入院後直ちにECUM之透析施行す るも血珐が維持できずに心不全と肺水腫で死亡し た。死亡後にneedle autopsyを施行した，本症例 の経過の概要は图 1cに示した。

\section{2. 入院時検查所見}

急性腎不全合併時の検査所見を表 1 に示した。 BUN，Crはいずれも高值を示していた。特徴的な ことは，腎不全時に大量の蛋白尿とともにTPが $3.6,4.4,3.5 \mathrm{~g} / \mathrm{dl}, \mathrm{Alb} 31.7,1.7,1.8 \mathrm{~g} / \mathrm{dl}$ と 3 症例とも著明な低蛋白血症を認めていた点であ 


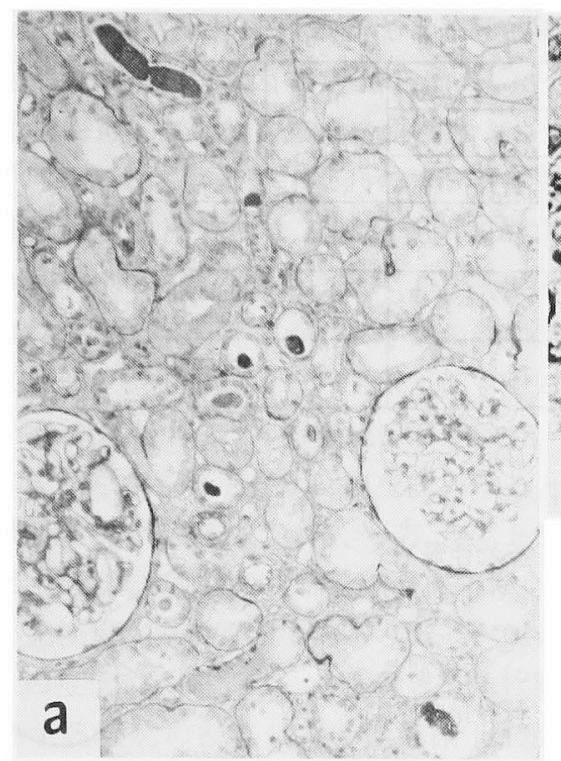

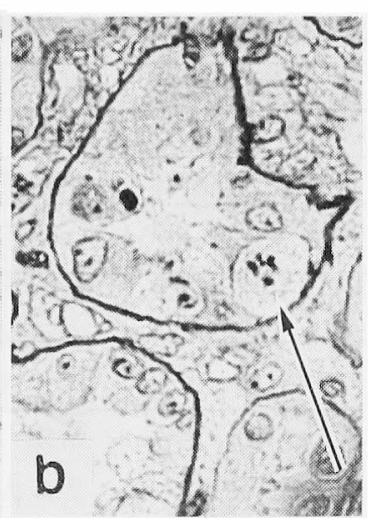

図 2,症例 1 の腎組織像：a）尿細管腔に蛋白円柱が 散見される。系球体には異常は認められない.(PAS染 色，×200，，b）尿細管上皮細胞質の腫脹と核の脱落, mitosisの所見を認める (矢印). (PAS染色, $\times 400$ )

表 2. 臨床像の比較

\begin{tabular}{|c|c|c|c|c|c|c|c|c|c|}
\hline \multirow{2}{*}{ 症例 } & \multirow{2}{*}{ 年令 } & \multirow{2}{*}{ 性 } & \multirow{2}{*}{$\begin{array}{l}\text { 急性腎不全に } \\
\text { 祭連した薬物 } \\
\text { の使用歴 }\end{array}$} & \multirow{2}{*}{ 高血圧 } & \multirow{2}{*}{$\begin{array}{c}\text { 血清アル } \\
\text { ブン値 } \\
(\mathrm{g} / \mathrm{dl})\end{array}$} & \multirow{2}{*}{$\begin{array}{c}\text { MCNS発症から } \\
\text { 急性珡全畣 } \\
\text { 併までの期間 }\end{array}$} & \multirow{2}{*}{ 治療 } & \multicolumn{2}{|c|}{ 予 後 } \\
\hline & & & & & & & & 腎不全 & ネフローゼ \\
\hline 1 & 23 & 男 & $(-)$ & $(-)$ & 1.7 & 7 日 & 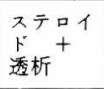 & $\begin{array}{c}\text { 透析 } 1 \text { 力月 } \\
\text { で離脱 }\end{array}$ & $\begin{array}{c}\text { 不完全寛解 } \\
\text { I 型 }\end{array}$ \\
\hline 2 & 54 & 男 & $(-)$ & $(+)$ & 1.7 & 約 6 力月 & $\begin{array}{l}\text { ステロイ } \\
\text { F木 }^{\text {㛢析 }}+\end{array}$ & 透析 1 力月 & $\begin{array}{c}\text { 不完全筧解 } \\
\text { I 型土地 }\end{array}$ \\
\hline 3 & 72 & 男 & $(-)$ & $(-)$ & 1.8 & 20日 & 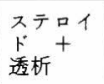 & $\begin{array}{l}\text { 心不全·肺 } \\
\text { 承腫を合併 } \\
\text { し死亡 }\end{array}$ & \\
\hline
\end{tabular}

る. 低補体血症はなく, 尿沈渣上赤血球は $0 \sim 1 /$ 視野であった。

\section{3. 臨床像の比較}

表 2 に 3 症例の臨床像を比較した. 年令は若年, 中年，高令に分かれ，性別ではすべて男性であっ た. 3 症例とも腎不全発症に関与したと考兄られ る薬物の使用は認められなかった。高血圧は症例 2 のみに認められた。血清アルブミン值は 3 症例 とも $2.0 \mathrm{~g} / \mathrm{dl}$ 以下であり, 高度な低蛋白血症を呈し ていた. MCNSの発症から急性腎不全合併までの 期間は, 症例 1 で 7 日, 症例 2 で約 6 力月, 症例 3 で20日と症例 1 と 3 で短期間であった。予後は 症例 1 と 2 が透析を約 1 カ月で離脱でき, 腎機能 の回復を認め, またステロイド療法後にネフロー
ゼ不完全寛解 I 型に回復した。症例 3 は, MCNS 発症後 1 カ月で死亡した.

\section{4. 腎組織像}

症例 1 （昭和61年 7 月 2 日, 利尿開始後 7 日目 の生検)：光顕所見は, 系球体には異常は認めな かった。間質では，尿細管腔に蛋白円柱が散見さ れた（図 2a)。また，一部の尿細管上皮細胞質の腫 脹と核の脱落, mitosisの所見が認められ(図 2b), 乏尿期には腎虚血の存在が可能性として考えられ た。間質細胞浸潤，血管の変化は認めなかった。 螢光所見はすべて陰性，電顕所見でも足突起融合 のみ認められた。

症例 $2 （$ 昭和 61 年 5 月 15 日，腎不全合併の約 5 カ月前の生検）：光顕所見は, 系球体には異常は 
表 3. 腎組織像の比較

\begin{tabular}{|c|c|c|c|c|c|c|c|c|c|}
\hline \multirow{3}{*}{ 症例 } & \multicolumn{4}{|r|}{ 光 } & 所 & 見 & & \multirow{3}{*}{ 螢光所見 } & \multirow{3}{*}{ 電顕所見 } \\
\hline & \multicolumn{2}{|c|}{ 系球体 } & \multicolumn{2}{|r|}{ 間 } & 質 & 尿 & 細 & & \\
\hline & 数 & 系球体 & 浮睡 & 細胞浸潤 & 血管变化 & mitosis & 腔内蛋白円柱 & & \\
\hline 1 & 16 & $\begin{array}{l}\text { minor } \\
\text { lesion }\end{array}$ & $(-)$ & $(-)$ & $(-)$ & $(+)$ & $(+)$ & $(-)$ & $\begin{array}{l}\text { minimal } \\
\text { change }\end{array}$ \\
\hline 2 & 6 & $\begin{array}{l}\text { minor } \\
\text { lesion }\end{array}$ & $(-)$ & $(-)$ & $(-)$ & $(-)$ & $(-)$ & $(-)$ & $\begin{array}{l}\text { minimal } \\
\text { change }\end{array}$ \\
\hline 3 & 30 & $\begin{array}{l}\text { minor } \\
\text { lesion }\end{array}$ & $(+)$ & $(-)$ & $(-)$ & $(-)$ & $(+)$ & $(-)$ & $\begin{array}{l}\text { minimal } \\
\text { change }\end{array}$ \\
\hline
\end{tabular}

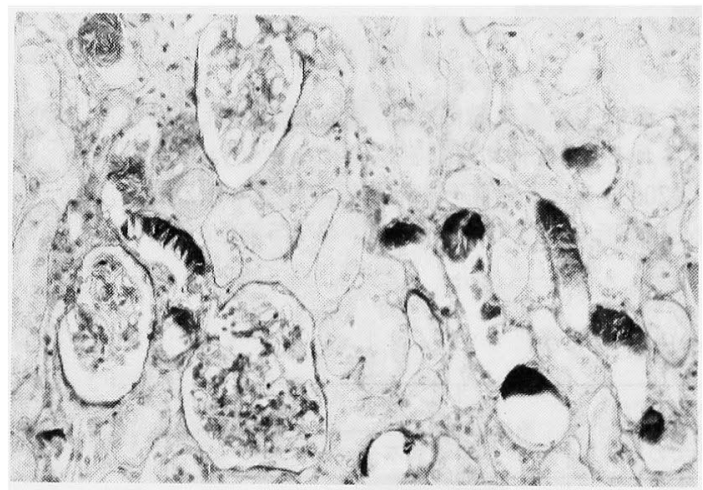

図 3.症例 3 の腎組織像：比較的多数の蛋白円柱と軽 度の間質浮腫を認める。系球体には異常は認められな い. (PAS染色, $\times 200)$

認めず, 間質性変化もなく, 䖝光所見も陰性, 電 顕所見も足突起融合のみであった。

症例 3 （昭和62年 1 月 10 日，腎不全合併時の 組織)：光顕所見は, 糸球体には異常は認められ なかった。間質では，尿細管腔に蛋白円柱が比較 的多数存在し, 軽度の間質浮腫が認められた（図 3 ). 螢光所見はすべて陰性, 電顕所見では足突起 融合のみ認められた。

以上の 3 症例の腎組織所見を表 3 に比較して示 した.

\section{考案}

MCNSにおける急性腎不全の成立機序につい ては，いまだ意見の一致はみられないが，図 4 に 示した機序が考号られている，すなわち，(1)薬物 による急性腎不全で, 抗生物質やフロセマイドな どによる間質性腎炎 ${ }^{16)}$, NSAID ${ }^{17)}$, 造影剤 ${ }^{18)}$ によ
(1) 薬物性腎不全
a）間質性腎炎
b) NSAID
c) 造影剂

(2) 腎静脈血栓症

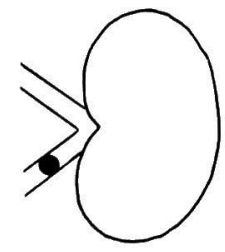

(3) 腎血流量减少
a）低血圧・ショック
b) 著明な低蛋白血症

(4) 尿細管腔蛋白円柱

(5) 腎間質浮腫
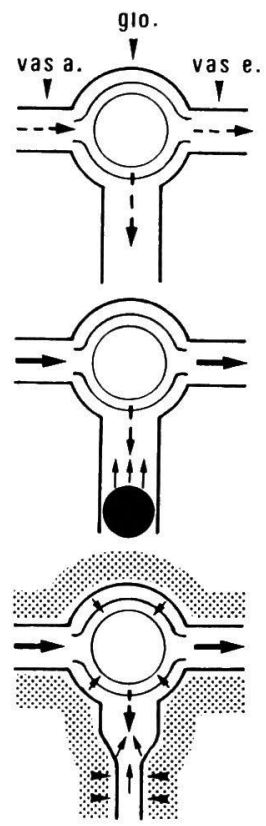

図 4.MCNSにおける急性腎不全発生機序

る腎障害, (2)ネフローゼ症候群の過凝固による腎 静脈血栓症 ${ }^{19)}$, (3)低血圧・ショックによる腎虚血, 腎血流量の減少とそれに続く急性尿細管壊死 ${ }^{20)}$, (4)尿細管腔蛋白円柱による尿細管閉塞7)15), (5)腎間 質浮腫 ${ }^{3) \sim 6)}$, である. (1), (2), (3)については, MCNS 
に限らず他のネフローゼ症候群でも一般的に認め 得る急性腎不全の原因之考古ら机る。とくに MCNSK特徵的な急性腎不全合併機序として, (4) と(5)が考えられている。すなわち腎間質浮腫また は尿細管腔蛋白円柱による尿細管閉塞である。 Lowensteinら゙は腎の間質浮腫により尿細管閉塞

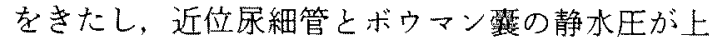
昇して限外汇過压が減少し，GFRが低下すると述 ベている. Sjobergら $5^{5}$ 腎機能は可逆性で，血液

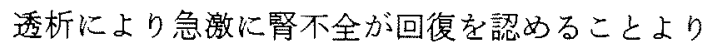
腎間質浮腫説を支持している。一方, 望月ら ${ }^{15}$ は女 児例で, 腎組織上多数の尿細管腔蛋白円柱を認め, これが急性腎不全の原因であろうと述べている。

我々の症例については，3症例とも急性腎不全 に関与する薬物の投与はなく，臨床上低血圧・ ショックは認められなかった。腎静脈血栓症につ いては，静脈造影は未施行なため確定的ではない が，腎ェコー上，腎腫大はなく腹痛も認めなかっ たため否定的であった。

腎組織学的に, 症例 1 では生検時期が利尿開始 後7日目であったため，組織所見は軽微であった が，腎虚血を推定させる所見を認めた。これは， 突然の大量蛋白尿のための急激な低蛋白凅症によ り，血管内脱水をきたして䇥有効循環血装量が低 下して腎虚血に宿った可能性があると推定され る。また，尿細管腔に蛋白円柱の形成が散見され た。症例 2 は, 腎生検時期が腎不全合併より 5 力 月前であったため, 組織学的に有意な所見は認め なかった。症例 3 は, 軽度ではあるが腎間質浮腫 を認めるとともに尿細管腔に蛋白円柱が比較的多 数認められた。この間質変化は尿細管閉塞を括こ して近位尿細管およびボウマン襄の静水王が上昇 し，GFRが低下したことを推察させる所見であ る.以上，我々の 3 症例に打ける急性腎不全の発 生機序は，組織所見上は軽度の変化であったが，

組織所見と臨床所見より以下の機序が推定され た。すなるち，突然発症的な大量蛋白尿による急 激な低蛋白血症により，a）腎虚血の可能性，b） 彗間質浮腫と尿細管腔蛋白円柱形成による尿細管 閉塞が考えられた。しかし，過去の報告例では腎
機能の回復は可逆的である報告が多い

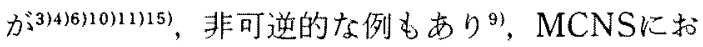
ける腎不全の原因を単一な機序にもとめることは 困難である。

また，他の因子として高血圧や高令者，血尿を 伴っている例に合併しやすいとの報告もあ る416)10)。ただ，大多数が著明な低蛋白血症を認め ている点で一致して扣り，低蛋白血症が急速に起 こったとすれば，急激な体内循環の变化が腎機能 に何らかの影響を与えている可能性は充分推察で きる.MCNSの発症早期の著明な低蛋白血症を認 めている状態下に沶いては，腎機能に対して慎重 な経過観察が必要と考えられた。

\section{結語}

微小变化型ネフローゼ症候群に急性腎不全を合 併した 3 症例について報告した。 その発生機序は， 突然の低蛋白血症により，a）腎虚血の可能性，b） 腎間質浮腫と尿細管腔蛋白円柱形成による尿細管 閉塞が考えられた。

\section{文献}

1) Chamberlain MJ, et al: Oliguric renal failure in the nephrotic syndrome. Q J I Med 35:215, 1966.

2) Conolly ME, et al: Reversible renal failure in idiopathic nephrotic syndrome with minimal glomerular changes. Lancet $1: 665,1968$.

3) Holdworth DR, et al: Reversible acute renal failure in the nephrotic syndrome with minimal glomerular pathology. Med J Aust 2:532, 1977.

4) Lowenstein J, et al: Renal failure in minimal change nephrotic syndrome. Amer J Med 70: 227, 1981.

5) Sjoberg RJ, et al : Renal failure with minimal change nephrotic syndrome. Reversal with hemodialysis. Clin Nephrology 20: 98, 1983.

6) Bernard D, Kiprov D: Case records of the Massachusetts General Hospital. New Engl J Med 304:221, 1982.

7) Imhasciati $\mathrm{E}$, et al: Acute renal failure in idiopathic nephrotic syndrome. Nephron 28: 186, 1981.

8) Hulter HN, Bonner EL: Lipid nephrosis appearing as acute oliguric renal failure. Arch Intern Med 140: 403, 1980

9) Raij L, et al: Irreversible acute renal failure 
in idiopathic nephrotic syndrome. Amer J Med $61: 207,1976$

10) Esparza AR, et al: Spectrum of acute renal failure in nephrotic syndrome with minimal (or minor) glomerular lesions. Role of hemodynamic factors. Lab Invest $45: 510,1981$.

11) Dash SC, et al: Reversible acute renal failure in idiopathic nephrotic syndrome with minimal change nephropathy. J Assoc Physicians 30: 399,1982

12) Thysell $\mathrm{H}$, et al: Plasma exchange in two cases of minimal change nephrotic syndrome with acute renal failure. Intern J Artif Org 6 : 75, 1983.

13) Scully RE, et al: Case records of the Massachusetts General Hospital. New Engl J Med 299: 136, 1978.

14) Cameron JS, et al: The nephrotic syndrome in adults with minimal glomerular lesions. Q J I Med 171: 461, 1974. 15）望月弘，他：急性腎不全を合併したminimal

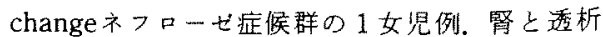
$18: 87,1985$

16) Lyon $\mathrm{H}$, et al: Allergic interstitial nephritis causing reversible renal failure in four patients with idiopathic nephrotic syndrome. New Engl J Med 288: 124, 1973.

17) Brezin $\mathrm{JH}$, et al: Reversible renal failure and nephrotic syndrome associated with nonster oidal antinflammatory drugs. New Engl J Med $301: 1271,1979$

18) Byrd L, Sherman RL: Radio contrast induced acute renal failure. A clinical and patho physiological review. Medicine 58: 270, 1979.

19) Cade $R$, et al : Chronic renal vein thrombosis. Amer J Med 63 : 387, 1977.

20) Yamauchi $\mathrm{H}$, et al: Hypovolemic shock and hypotention as a complication of the nephrotic syndrome. Ann Intern Med $60: 242,1964$. 